\title{
Distribution Pattern of Sweet Potato Whitefly Bemisia tabaci (Gennadius) on Tomato Plants
}

\author{
K.M. Azam ${ }^{1}$, S.A. Razvi, M.H. Al-Muhthuri and A.A. Al-Raeesi \\ Department of Agronomy, Horticulture, Entomology and Plant Pathology, \\ College of Agriculture, Sultan Qaboos University, P.O. Box 34, Al Khod 123, \\ Sultanate of Oman
}

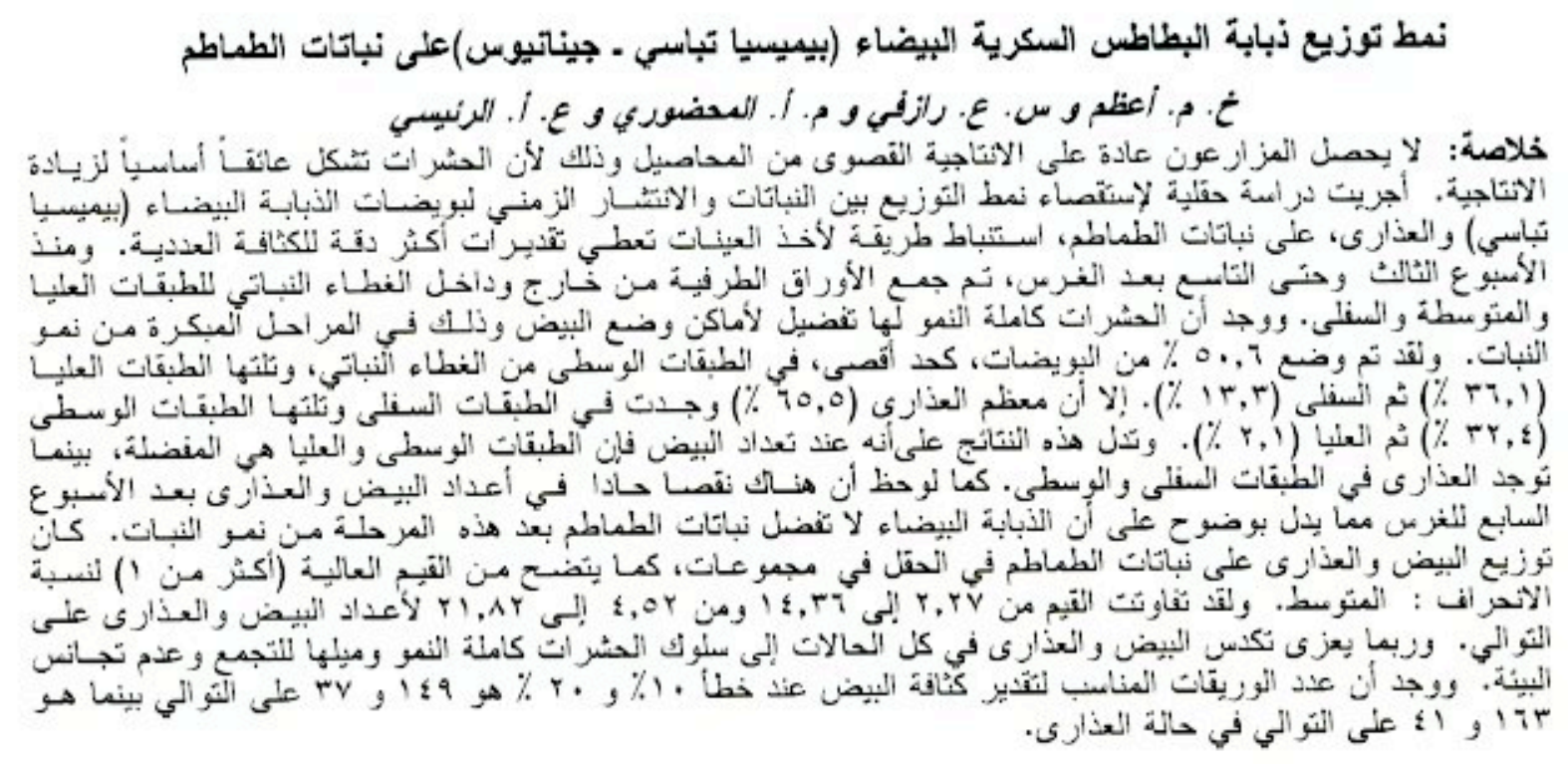

\begin{abstract}
A field experiment was conducted to study the intra plant distribution and temporal dispersion patterns of whitefly (Bemisia tabaci Gennadius) eggs and nymphs on tomato plants to establish a sampling method which would give accurate estimates of the population size. From the third week to the ninth week after transplanting, terminal leaflets were collected from the outer and inner canopies of each of the upper, middle, and lower plant strata. A strong ovipositional preference was found in whitefly adults at an early crop age. A maximum of $50.6 \%$ of the eggs were deposited in the middle stratum followed by upper $(36.1 \%)$ and lower strata $(13.3 \%)$. However, most of the nymphs $(65.5 \%)$ were present in the lower stratum followed by middle $(32.4 \%)$ and upper strata $(2.1 \%)$. These findings indicated that when taking observations in egg counts the most preferred site is the upper and middle strata while for nymphal counts it is the lower and middle strata. There was a sharp decrease in egg and nymphal counts from the seventh week after transplantation which clearly indicated that, after this age, the crop is not preferred by whitefly. Egg and nymphal populations of whitefly on tomato plants in the field were distributed in aggregates as evident by high variance to mean ratio. Values ranged from 2.72 to 14.36 and 4.52 to 21.82 for egg counts and nymphal population, respectively. Aggregation of whitefly eggs and nymphs in all cases might be due to the behaviour of adults to congregate and to the heterogeneity of the environment. The appropriate number of leaflets required for the estimation of egg density at $10 \%$ and $20 \%$ error was found to be 149 and 37 , respectively. In the case of nymphal population the numbers were 163 and 41 at $10 \%$ and $20 \%$ error, respectively.
\end{abstract}

$\mathrm{T}$ omato (Lycopersicum esculentum), one of the important vegetable crops, suffers from as many as 57 insect species (Hill, 1987). However, only about six insect species have been observed attacking it in the Gulf region. Among these the most predominant, is the sweet potato whitefly, Bemisia tabaci (Gennadius).

B. tabaci is polyphagous pest having at least 500 host plants (Greathead, 1986). It is distributed throughout warm and tropical areas of the world such as Oman, Sudan, India, Egypt, Turkey, Greece, Central America and Thailand. Due to its wide adaptability, and its ability to cause extensive crop damage directly and indirectly, and its ability to withstand many commonly used insecticides, this pest poses a major problem to vegetable growers around the world.

In arid climates, such as Oman, whitefly is one of the major pests infesting vegetables and pulses. Both nymphs and adults feed voraciously on the plant sap and when present in sufficient numbers, cause leaf drop and prohibit fruit maturation (Pollard, 1955). The insects produce sticky honey dew which serves as a 
medium for the development of sooty mold fungus, which inhibits photosynthesis in leaves (Perkins, 1983). In addition to their pest status, whiteflies also play a major role in transmission and dissemination of tomato leaf curl virus (TLCV) which results in curling and shortening of leaves and stunting of plant growth (Muniyappa, 1980; Dhaju and Verma, 1986).

Investigations on $B$. tabaci require a sampling method which will give reliable estimates of the pest population with a minimum of labour. Estimation of an insect population depends upon the population density, sampling technique, and the degree of its aggregation. Knowledge of the dispersion of the insect population plays a pivotal role in planning the sampling procedure for the study of natural insect populations (Southwood, 1978).

Information is available on distribution patterns of whitefly on crops like cotton and cassava. In cotton, it has been suggested that the leaves on the main stem nodes number 3-7 should be examined to get the best estimates (Ohensorge and Rapp, 1986). In the case of cassava, Abisgold and Fishfool (1990) devised a method for estimating whitefly populations and suggested the examination of sectors 3-5 of leaves 7-20 to get an accurate estimate. Though sampling procedures for whitefly were reported for the tomato crop (Schuster et. al., 1989), no information was available on the pest distribution pattern. Hence, there is a need to study the distribution pattern of whitefly in the foliar canopy of tomato plants to establish a sampling method which can give an accurate estimate of the insect population in the field. This study was undertaken to determine a method to accurately estimate the whitefly population in the field.

\section{Materials and Methods}

Tomato seedlings of a susceptible variety (Ace 55) were transplanted during the cropping season on 5 December 1994, in three plots each $18 \times 9 \mathrm{~m}^{2}$ by maintaining a spacing of $150 \mathrm{~cm}$ between rows and 50 $\mathrm{cm}$ between plants. In each plot, there were 13 rows ( $9 \mathrm{~m}$ in length) and in each row there were 19 plants. The crop was grown with drip irrigation following recommended agronomic practices. No insecticide was applied to plants to encourage insect population. Observations were recorded for number of eggs and nymphs on leaflets in six strata (treatments) with three replications for $7 \mathrm{wk}$. The treatments were: (1) Upper stratum, outer terminal leaflets; (2) Upper stratum, inner terminal leaflets; (3) Middle stratum, outer terminal leaflets; (4) Middle stratum, inner terminal leaflets; (5) Lower stratum, outer terminal leaflets; (6) Lower stratum, inner terminal leaflets. Experiments were conducted at the Agricultural Experiment Station, Sultan Qaboos University.
In all studies, the upper stratum refers to the young leaflets taken from the top one third portion of the plant, while middle and lower strata refer to the middle age of fully grown leaflets of the plants taken from the middle one third and bottom one third portions of the plant, respectively. The inner terminal leaflets refer to the leaflets which are in the plant canopy and the outer leaflets refer to the leaflets fully exposed.

Samples were collected at weekly intervals from week 3-9 after transplanting. Three field rows were selected at the rate of one row per plot. From each row ten plants were selected at random. From each plant six terminal leaflets were taken at the rate of one leaflet from each of the six positions in the plant which formed the different strata (treatments). The leaflets were taken to the laboratory and examined under a binocular microscope and the total number of eggs and nymphs present on the lower surface of each leaflet was recorded. The mean number of eggs and nymphs per leaflet in each stratum was calculated. The dispersion pattern of whitefly in the tomato crop and the sample size required was determined using the data which showed a high mean population (average of 30 samples) on each observation date, from among the six selected sites.

STATISTICAL ANALYSIS: Variance to mean ratio $\left(\mathrm{S}^{2} / \bar{x}\right)$ and the dispersion parameter $(\mathrm{k})$ were calculated according to Southwood (1978). If the value of $\mathrm{k}$ is below eight then it indicates the population is aggregated. Morisita's Index of dispersion, Iô, was calculated following Morisita (1962). The significance of departure from randomness was tested by the F test. The appropriate number of samples $(\mathrm{N})$ required for the estimation of populations of the insect with aggregated distribution was calculated following the procedure outlined by Southwood (1978):

$$
\begin{aligned}
& \mathrm{k}=(\overline{\mathrm{x}})^{2} /\left(\mathrm{S}^{2}-\overline{\mathrm{x}}\right) \\
& \text { where } k=\text { dispersion parameter } \text {, } \\
& S^{2}=\text { variance, and } \\
& \bar{x}=\text { mean. } \\
& \left.\mathrm{I} \delta=\mathrm{N}\left(\Sigma \mathrm{x}^{2}-\Sigma \mathrm{x}\right) /\left[(\Sigma \mathrm{x})^{2}-\Sigma \mathrm{x}\right)\right] \\
& \text { where } \mathrm{I} \delta=\text { Morisita's index, } \\
& N=\text { sample size, } \\
& x=\text { number of individuals in } \\
& \text { each sample. } \\
& \mathrm{F}=[\mathrm{I} \delta(\Sigma \mathrm{x}-1)+(\mathrm{N}-\Sigma \mathrm{x})] /(\mathrm{N}-1) \\
& \text { where } F=\text { calculated value of } F \text {-test for } \\
& \text { testing the significance of } \\
& \text { the treatment effect. }
\end{aligned}
$$




$$
\begin{gathered}
\qquad \mathrm{N}=(1 / \overline{\times}+1 / \mathrm{k}) / \mathrm{D}^{2} \\
D^{2}=\text { margin of error expressed as fraction of } \\
\text { plot mean taken as } 10 \% \text { and } 20 \% .
\end{gathered}
$$

\section{Results and Discussion}

DISTRIBUTION OF WHITEFLY EGGS ON TOMATO PLANTS: The seasonal mean of seven observations (Table 1) indicated that 4.48 eggs/leaflet (50.6\%) were deposited on the leaflets in the middle stratum followed by 3.19 eggs/leaflet $(36.1 \%)$ on the upper stratum. These results were significantly higher in comparison to the lower stratum with 1.18 eggs/leaflet (13.3\%). The insect showed the least ovipositional preference, 1.16 eggs/leaflet $(6.6 \%)$ and 1.19 eggs/leaflet $(6.7 \%)$ to the outer and inner terminal leaflets of the lower stratum and less preference, 3.65 eggs/leaflet $(20.6 \%)$ and 2.73 eggs/leaflet $(15.4 \%)$, to the inner and outer terminal leaflets of the upper stratum, respectively. There was no difference $(\mathrm{P}>0.05)$ in egg counts between the outer and inner terminal leaflets of each stratum. However, high oviposition, 4.70 eggs/leaflet $(26.6 \%)$ and 4.26 eggs/leaflet $(24.1 \%)$ was observed on the outer and inner terminal leaflets of the middle stratum. This trend (Figure 1) showed that the insect prefers to oviposit on the middle and upper strata where young leaflets are available. Also, the middle stratum gets more shade. This might provide a more favourable microclimatic condition for oviposition.

DISTRIBUTION OF WHITEFLY NYMPHS ON TOMATO PLANTS: A comparison of nymphal counts on the three major strata indicates that the count in the lower stratum, 7.05 nymphs/leaflet $(65.5 \%)$, was higher ( $\mathrm{P}<0.05)$ compared to 3.49 nymphs/leaflet $(32.4 \%)$ in the middle stratum and 0.22 nymphs/leaflet $(2.1 \%)$ in the upper stratum. However, Rao et, al. (1991) reported that the large number of nymphs on cotton leaves was confined to the middle portion of the plant. The difference in findings could be attributed to crop variation. The nymph population showed least occupational site both on outer and inner terminal leaflets of the upper stratum with 0.30 nymphs/leaflet $(1.39 \%)$ and 0.14 nymphs/leaflet $(0.65 \%)$, respectively. The outer and inner terminal leaflets of the middle

TABLE 1

\begin{tabular}{|c|c|c|c|c|c|c|c|c|c|c|}
\hline \multicolumn{2}{|c|}{ Plant Canopy } & \multicolumn{7}{|c|}{ Week after transplanting } & \multirow[b]{2}{*}{ Mean' } & \multirow[b]{2}{*}{ Pooled Mean' } \\
\hline & & 3 rd & 4th & 5th & 6th & 7 th & 8 th & 9th & & \\
\hline \multirow[t]{2}{*}{ USOTL' } & $\bar{x}$ & 9.03 & 4.57 & 3.37 & 1.87 & 2.43 & 2.60 & 1.70 & $3.65^{\text {th }}(20.63 \%)$ & \multirow[b]{2}{*}{$3.19 *(36.05 \%)$} \\
\hline & $\mathrm{SD}$ & 12.11 & 4.46 & 3.98 & 3.14 & 2.90 & 5.89 & 4.50 & 3.18 & \\
\hline \multirow[t]{2}{*}{ USITL $^{2}$} & ₹ & 4.37 & 2.50 & 1.23 & 1.23 & 4.90 & 1.93 & 2.97 & \multirow{2}{*}{$\begin{array}{c}2.73^{h}(15.43 \%) \\
2.04\end{array}$} & \\
\hline & SD & 4.58 & 3.54 & 1.81 & 1.97 & 7.46 & 2.77 & 4.10 & & \\
\hline \multirow[t]{2}{*}{$\mathrm{MSOTL}^{3}$} & $x$ & 9.23 & 4.30 & 6.47 & 5.33 & 1.37 & 1.73 & 1.37 & \multirow{2}{*}{$\begin{array}{c}4.26^{-h}(24.08 \%) \\
3.53\end{array}$} & \\
\hline & $\mathrm{SD}$ & 10.30 & 5.78 & 6.64 & 3.87 & 2.04 & 2.68 & 1.96 & & $4.48 *(50.62 \%)$ \\
\hline \multirow[t]{2}{*}{ MSITL ${ }^{*}$} & $x$ & 6.67 & 5.10 & 6.80 & 3.00 & 5.20 & 3.43 & 2.70 & \multirow{2}{*}{$\begin{array}{c}4.7 u r(26.57 \%) \\
2.75\end{array}$} & \\
\hline & SD & 8.35 & 8.70 & 7.37 & 3.55 & 4.38 & 4.50 & 4.35 & & \\
\hline \multirow[t]{2}{*}{ LSOTL } & 又. & 2.40 & 1.03 & 1.53 & 1.93 & 0.73 & 0.40 & 0.07 & \multirow{2}{*}{$\begin{array}{c}1.16(6.56 \%) \\
1.14\end{array}$} & \\
\hline & $\mathrm{SD}$ & 3.76 & 2.22 & 2.13 & 4.11 & 2.38 & 1.04 & 0.25 & & $1.18^{h}(13.33 \%)$ \\
\hline \multirow[t]{2}{*}{ LSITL } & $\bar{x}$ & 1.73 & 0.50 & 3.57 & 1.37 & 0.27 & 0.60 & 0.27 & \multirow{2}{*}{$\begin{array}{c}1.1 \%(6.73 \%) \\
1.30\end{array}$} & \\
\hline & $\mathrm{SD}$ & 5.63 & 1.46 & 4.96 & 2.04 & 0.58 & 1.38 & 0.58 & & \\
\hline \multirow{2}{*}{\multicolumn{2}{|c|}{$\begin{array}{l}\text { F-value } \\
\mathrm{CD}_{0.09}\end{array}$}} & $3,48^{*}$ & 1.50 & $7.65^{*}$ & $3.57 *$ & $3.75^{*}$ & 2.19 & 3.12 & & \\
\hline & & 5.492 & NS & 2.699 & 2.567 & 3.456 & NS & NS & & \\
\hline \multirow{2}{*}{$\begin{array}{l}\text { Full } \\
\text { canopy }\end{array}$} & $\vec{x}$ & $5.57^{\circ}$ & $3.00^{\circ}$ & $3.83^{m}$ & $2.46^{\circ \mathrm{c}}$ & $2.48^{\star}$ & $1.75^{\circ}$ & $1.51^{\circ}$ & & \\
\hline & $\mathrm{SD}$ & 4.07 & 2.83 & 2.64 & 1.83 & 2.47 & 1.54 & 1.64 & & \\
\hline
\end{tabular}

Distribution of whitefly eggs per leaflet on tomato plants under field conditions

Upper stratum outer terminal leaflet.

${ }^{2}$ Upper stratum inner terminal leaflet.

${ }^{3}$ Middle stratum outer terminal leaflet.

"Middle stratum inner terminal leaflet.

'Lower stratum outer terminal leaflet.

Lower stratum inner terminal leaflet.

Teans per leaflet.

'Means of outer and inner terminal leaflets.

*, $\mathrm{P}<0.05 ; \mathrm{NS}, \mathrm{P}>0.05$.

Figures in parencheses are percentage tranformed values. 

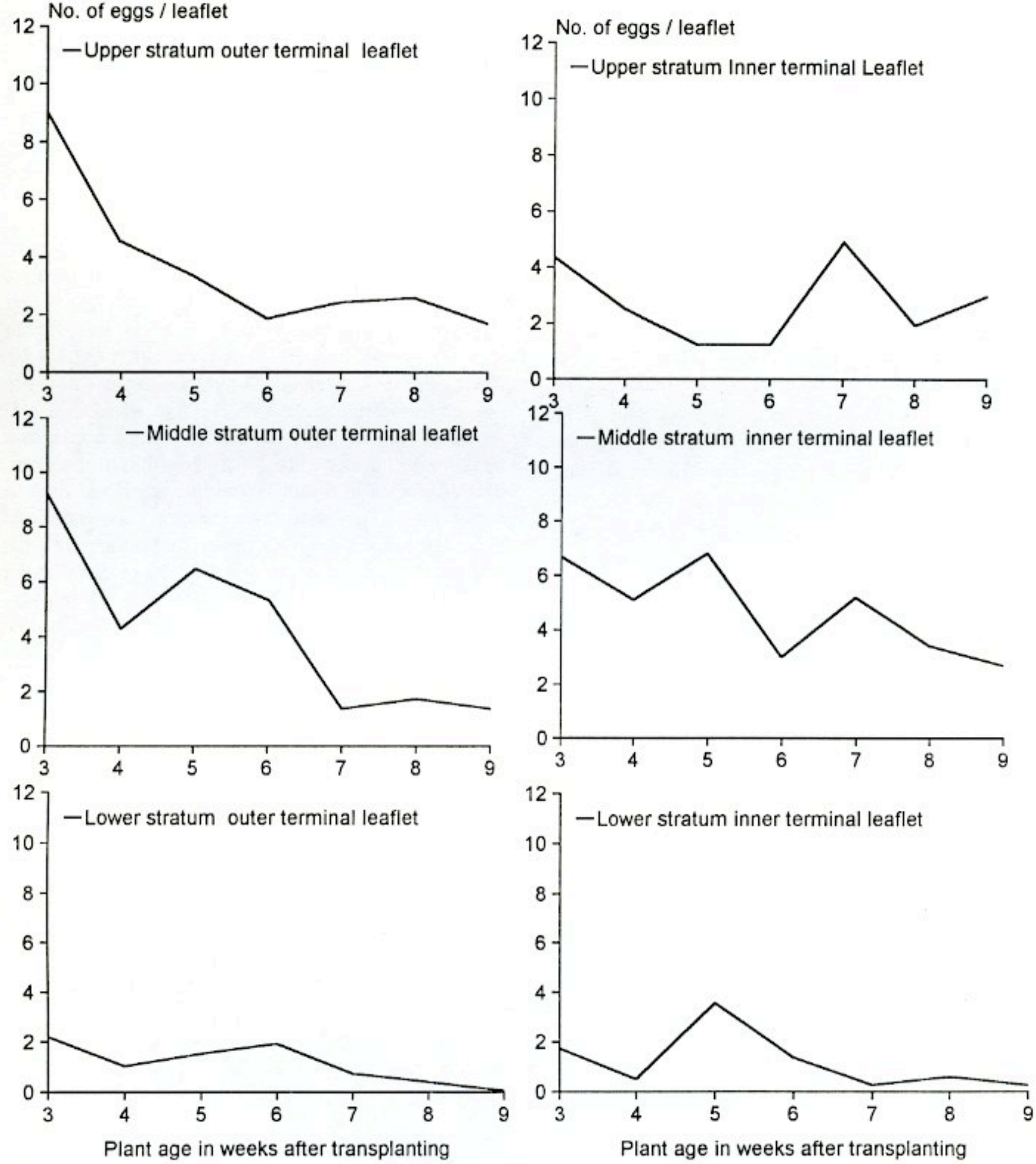

Figure 1. The mean number of whitefly eggs per leaflet recorded on different strata at various ages of tomato plant.

stratum showed moderate occupational site with 4.20 nymphs/leaflet $(19.5 \%)$ and 2.79 nymphs/leaflet $(12.95 \%)$, respectively. This was higher $(\mathrm{P}<0.05)$ than those found in upper stratum. The lower stratum had the maximum number of nymphs on both the outer and inner terminal leaflets with 8.25 nymphs/leaflet $(38.3 \%)$ and 5.86 nymphs/leaflet $(27.21 \%)$, respectively. This was higher $(\mathrm{P}<0.05)$ than those found in the middle and upper strata. However, among the six strata, the ideal site to collect samples for whitefly nymphs was the middle stratum outer terminal leaflets up to three wk after transplanting. At a later plant age, the leaflet samples should be collected from the lower stratum outer terminal leaflets. (Figure 2).

PLANT AGE IN RELATION TO THE EGG AND NYMPHAL POPULATION OF THE WHITEFLY: Egg counts were the highest $(5.57 /$ leaflet $)$ at $3 \mathrm{wk}$ after transplanting. It subsequently decreased to $3.00,3.83,2.46,2.48$ and 1.75 eggs/leaflet at $4,5,6,7$ and 8 wk after 

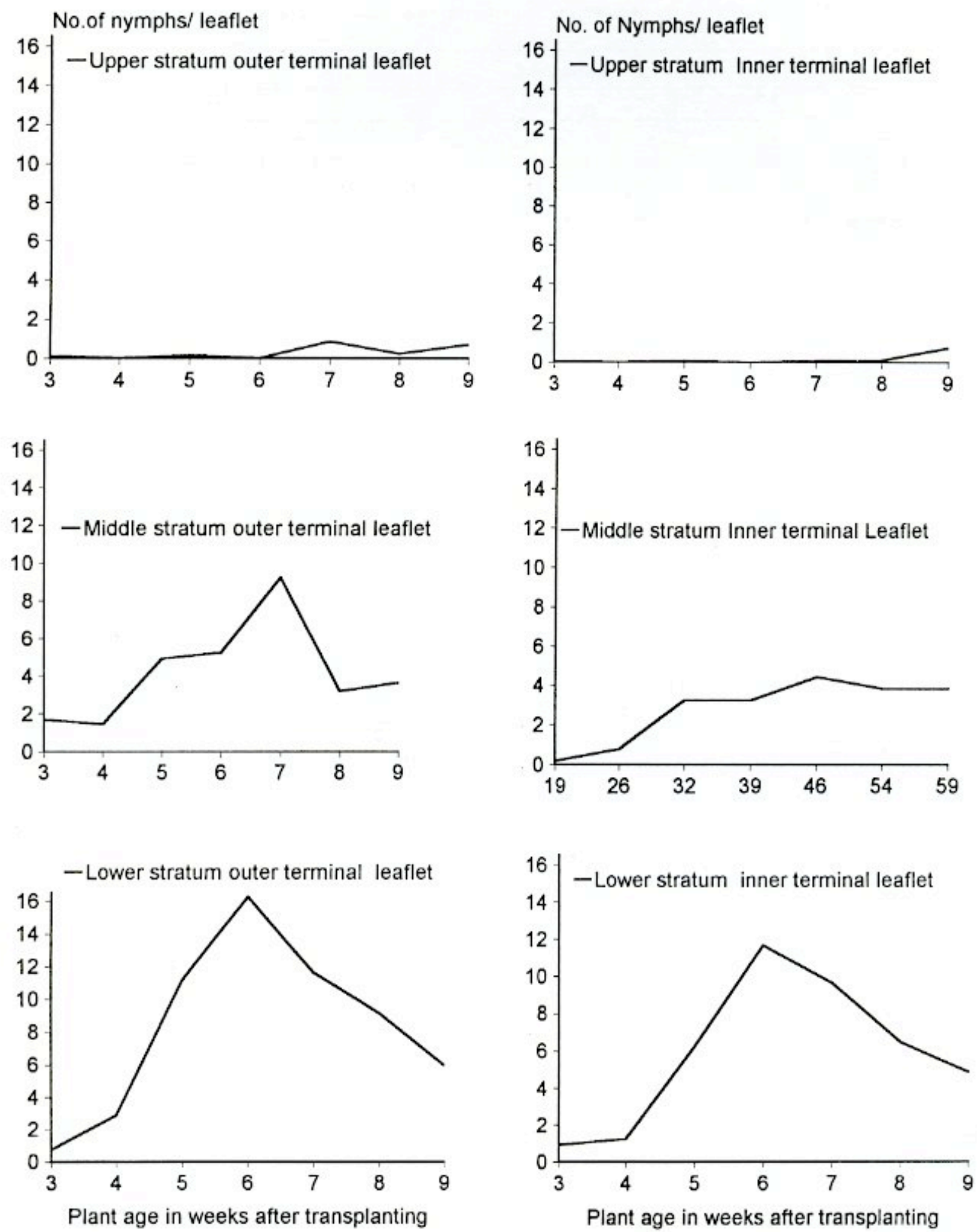

Figure 2. The mean number of whitefly nymphs per leaflet recorded on different strata at various ages of tomato plant.

transplanting, respectively. A minimum of 1.51 eggs/leaflet was recorded at 9 wk after transplanting. This shows a strong ovipositional preference with early age of the crop (Table 1 and Figure 3). There exists a highly negative correlation $(\mathrm{P}<0.01)$ between oviposition and the age of the crop $(r=-0.4065)$. The nymphal population as recorded at 3 wk after transplanting was the least ( 0.61 nymphs/leaflet), but it 
TABLE 2

Distribution of whitefly nymphs per leaflet on tomato plants under field conditions.

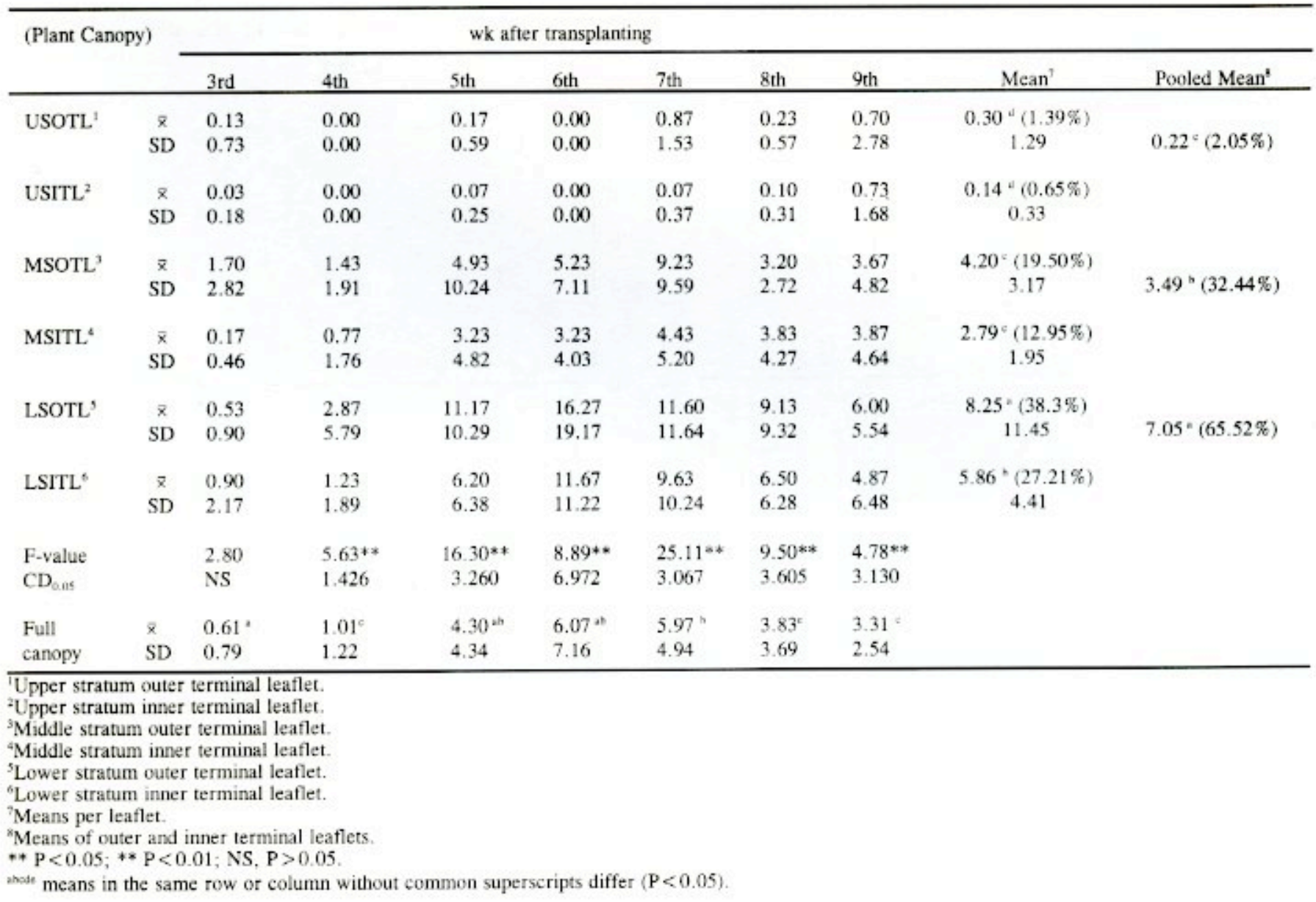

increased with age. The mean number of nymphs recorded at 4,5,6 and 7 wk after transplanting was $1.01,4.30,6.07$ and 5.97 nymphs/leaflet, respectively. This was followed by a rapid decline in the population count from week 7 . The nymphal population recorded on week 8 and 9 were 3.83 and 3.31 nymphs/leaflet, respectively (Table 2 and Figure 3 ). There exists a positive correlation $(\mathrm{P}<0.01)$ between nymphal population and the age of the crop $(r=0.2466)$.

TEMPORAL DISTRIBUTION PATTERN OF WHITEFLY EGGS ON TOMATO PLANTS: Since a greater number of whitefly eggs were recorded from the middle stratum throughout the season, data from this section was used to study the dispersion of whitefly eggs on tomato crops and to determine the sample size required to estimate egg population at the respective age of the crop. The mean egg count $(\bar{x})$ was high $(9.2$ eggs/leaflet) when the crop was 3 wk old, the number of eggs decreasing with crop age. The variance to mean ratio $\left(\mathrm{S}^{2} / \bar{x}\right)$ were high (more than one) ranging from 2.72 to 14.36 at all ages of the crop indicating that whitefly egg laying follows an aggregated distribution (Table 3 ).
The values of Morisita's index (Iס) at all ages of the crop were found to be more than unity (ranging

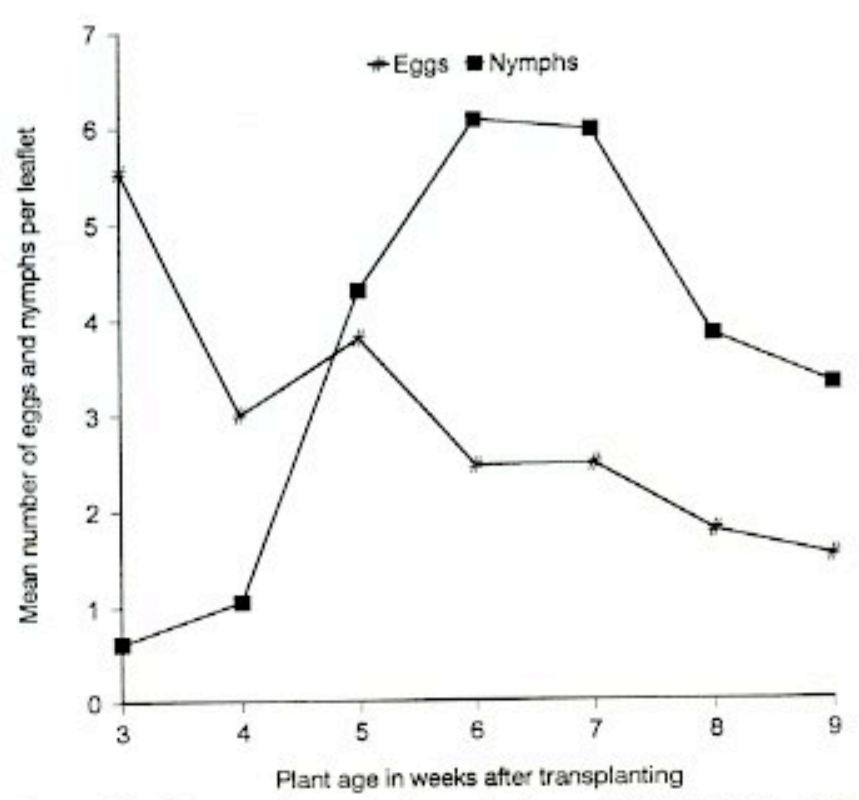

Figure 3. Eggs and nymphal populations of whitefly Bemisia tabaci in relation to the age of tomato crop 
DISTRIBUTION PATTERN OF SWEET POTATO WHITEFLY

TABLE 3

Dispersion of eggs of Bemisia tabaci on tomato crop under field conditions

\begin{tabular}{|c|c|c|c|c|c|c|c|c|}
\hline \multirow[t]{2}{*}{ Age of the Crop* } & \multirow[t]{2}{*}{$\begin{array}{l}\text { Mean } \\
\text { Population ** }\end{array}$} & \multirow[t]{2}{*}{ Variance } & \multirow[t]{2}{*}{ Variance : Mean } & \multirow[t]{2}{*}{$\begin{array}{l}\text { Morisita's } \\
\text { Index (I } 8 \text { ) }\end{array}$} & \multirow[t]{2}{*}{$\begin{array}{l}\text { Calculated } \\
\text { F }\end{array}$} & \multirow[t]{2}{*}{$\begin{array}{l}\text { Dispersion } \\
\text { Parameter }\end{array}$} & \multicolumn{2}{|c|}{$\begin{array}{l}\text { Appropriate number of } \\
\text { samples }\end{array}$} \\
\hline & & & & & & & $10 \%$ error & $20 \%$ error \\
\hline 3 & 9.23 & 102.58 & 11.11 & 2.10 & $11.583^{* *}$ & 0.91 & 121 & 30 \\
\hline 4 & 5.10 & 73.22 & 14.36 & 3.64 & $14.837 * *$ & 0.38 & 283 & 71 \\
\hline 5 & 6.47 & 42.58 & 6.58 & 1.87 & $6.793 * *$ & 1.16 & 102 & 25 \\
\hline 6 & 5.33 & 14.49 & 2.72 & 1.33 & $2.798^{* *}$ & 3.10 & 51 & 13 \\
\hline 7 & 5.20 & 18.56 & 3.57 & 1.50 & $3.672^{* *}$ & 2.02 & 69 & 17 \\
\hline 8 & 3.43 & 19.58 & 5.71 & 2.39 & $5.884^{8 *}$ & 0.73 & 166 & 42 \\
\hline 9 & 2.70 & 18.28 & 6.77 & 4.00 & $9.276^{* *}$ & 0.47 & 250 & 62 \\
\hline
\end{tabular}

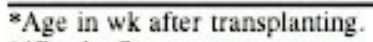

**Per leaflet.

***Significant at $1 \%$ level.

TABLE 4

Dispersion of nymphal population of Bemisia tabaci on tomato crop under field conditions

\begin{tabular}{|c|c|c|c|c|c|c|c|c|}
\hline \multirow[t]{2}{*}{ Age of the Crop* } & \multirow[t]{2}{*}{$\begin{array}{l}\text { Mean } \\
\text { Population ** }\end{array}$} & \multirow[t]{2}{*}{ Variance } & \multirow[t]{2}{*}{ Variance : Mean } & \multirow[t]{2}{*}{$\begin{array}{l}\text { Morisita's } \\
\text { Index (18) }\end{array}$} & \multirow[t]{2}{*}{$\begin{array}{l}\text { Calculated } \\
\text { F }\end{array}$} & \multirow[t]{2}{*}{$\begin{array}{l}\text { Dispersion } \\
\text { Parameter }\end{array}$} & \multicolumn{2}{|c|}{$\begin{array}{l}\text { Appropriate number of } \\
\text { samples }\end{array}$} \\
\hline & & & & & & & $10 \%$ error & $20 \%$ error \\
\hline 3 & 1.70 & 7.68 & 4.52 & 3.13 & $4.672^{* * *}$ & 0.48 & 267 & 67 \\
\hline 4 & 2.87 & 32.45 & 11.31 & 4.65 & $11.711^{* 8 *}$ & 0.28 & 391 & 98 \\
\hline 5 & 11.17 & 102.34 & 9.16 & 1.74 & $9.525 * * *$ & 1.36 & 82 & 21 \\
\hline 6 & 16.27 & 355.06 & 21.82 & 2.29 & $22.667^{* * *}$ & 0.78 & 134 & 34 \\
\hline 7 & 11.60 & 130.97 & 11.29 & 1.89 & $11.649^{* * *}$ & 1.33 & 83 & 21 \\
\hline 8 & 9.13 & 83.91 & 9.19 & 1.90 & $9.469 * * *$ & 1.11 & 101 & 25 \\
\hline 9 & 6.0 & 29.67 & 4.94 & 1.67 & $5,136^{* * * *}$ & 1.52 & 82 & 21 \\
\hline
\end{tabular}

*Age in wk after transplanting.

**Per leaflet.

$* * *$ Significant at $1 \%$ level.

from 1.33 to 4.00 ) thus supporting the aggregated egg distribution pattern. The population distribution pattern can also be adequately explained by the exponent $\mathrm{k}$ of the negative binomial, which is an index of aggregation in the population. The values of $\mathrm{k}$ ranged from 0.38 to 3.10 , which are below eight. This supports the premise that whitefly eggs were aggregated at all ages of observation. The departure of the egg distribution from randomness, assessed by the F-test was found to be highly significant (Table 3 ). The higher magnitude of whitefly egg aggregation on leaves of the upper and middle strata might be due to the preference of females for laying eggs on younger leaflets.

The optimum number of leaflet samples, $(\mathrm{N})$, required for estimating the number of individuals in a population was high when the plants were 4 and $9 \mathrm{wk}$ old. The $\mathrm{N}$ values for 4 and 9 wk old crops being 283 and 250 , at $10 \%$ error, and 71 and 62 at $20 \%$ error, respectively. However, for 5 to $8 \mathrm{wk}$ old crops it ranged from 51 to 166 at $10 \%$ error and 13 to 42 at
$20 \%$ error (Table 3 ).

TEMPORAL DISTRIBUTION PATTERN OF WHITEFLY NYMPHS ON TOMATO CROPS: High mean populations of $2.9,11.2,16.3,11.6,9.1$ and 6.0 nymphs per leaflet were confined to lower stratum outer terminal leaflets from 4-9 wk after transplanting. However, during third week after transplanting a high population of 1.7 nymphs per leaflet was confined to the middle stratum outer terminal leaflets. The same data were used to study the dispersion of whitefly nymphs and the sample size required to estimate the insect population. The variance to mean ratio $\left(\mathrm{S}^{2} / \bar{x}\right)$ were found to be greater than one at all ages of observation ranging from 4.5 to 21.8 , indicating that the dispersion of the nymphs follows an aggregated pattern. Similar distribution patterns were reported by Singh et al. (1990) on adult whitefly on cotton, Naranjo and Flint (1994) on eggs and nymphs of whitefly on cotton, and Liu and Oetting (1993) on all stages of whitefly on poinsettia. 
The value of, I $\delta$ ranged from 1.67 to 4.65 which showed that whitefly nymphs followed an aggregated type of dispersion. The departure of the nymph distribution from randomness, as assessed by the F-test, was found to be highly significant (Table 4). The values of $\mathrm{k}$ ranged from 0.28 at $4 \mathrm{wk}$ of age to 1.52 at 9 wk of age, indicated that the population of whitefly was distributed in an aggregated pattern. The possible reasons for this may be the behavioural patterns of the pest. This was also suggested by Singh et al, (1990) while studying the dispersion of whitefly population on cotton crops.

At low mean nymphal populations of 1.7 and 2.9 nymphs/leaflet, the appropriate number of plants required for observation were 267 and 391 at $10 \%$ error and 67 and 98 at $20 \%$ error, respectively. Singh et al. (1990) also reported that for the low values of pest density, the appropriate number of samples $\mathrm{N}$ required was high. A decrease in the value of $\mathrm{N}$ was observed with an increase in the mean pest population, resulting in the need to observe 83 to 134 plant samples at $10 \%$ error. However, a sample size of 21 to 34 was sufficient at $20 \%$ error (Table 4 ).

\section{Conclusions}

There was a strong ovipositional preference in whitefly adults at an early crop age. Most of the eggs were present on the upper and middle strata and nymphs were present in the lower and middle strata. Egg and nymphal populations followed an aggregated distribution. The approximate number of leaflets required per treatment for the estimation of egg densities at $10 \%$ and $20 \%$ error was found to be 149 and 37 , respectively while in the case of nymphal population it was 163 and 41 at $10 \%$ and $20 \%$ error, respectively.

\section{References}

Abisgold, J.D. and L.D.C. Fishpool. 1990. A method for estimating population sizes of whitefly nymphs (Bemisia tabaci Gennadius) on cassava. Tropical Pest Management,
$36(3): 287-292$

Dhanju, K.S. and J.P. Verma, 1986. Natural occurrence of mixed infection of tomato leaf curl virus and tomato mosaic virus in tomato. Indian Journal of Virology 1: 108-110.

Greathead, A.H. 1986. Host plants. In: Bemisia tabaci - a literature survey of the cotton whitefly with an annotated bibliography. M.J.W. Cook, Editor. p. 17-25 . C.A.B. Int. Inst. Biol. Control, London.

Hill, D.S. 1987. Agricultural Insect Pests of Temperate Regions and Their Control. Cambridge: University Press. $659 \mathrm{pp}$.

Liu, T.X. and G.D. Oetting. 1993. Distribution of Trialeurodes vaporariorum and Bemisia tabaci (Homoptera : Aleyrodidae) on some green houses ornamental plants. Journal of Entomology Science 28:102-112.

Mahal, M.S, and Balraj Singh. 1981. Distribution pattern of nymphs of the cotton jassid. Amrasca biguttula (Ishida) on different varieties of okra 8:41-49.

Morisita, M. 1962. Io Index, a measure of dispersion of individuals. Res. Popu. Ecol. Kyoto, Univ, 4:1-7.

Muniyappa, V. 1980. Whiteflies. In: Vectors of Plant Pathogens. K.F. Harris and Maramorasch (Editors).p. 39-85. Academic Press, New York.

Naranjo, S.E. and H.M. Flint. 1994. Spatial distribution of preimaginal Bemisia tabaci (Homoptera : Aleyrodidae) in cotton and development of fixed - precision sequential sampling plants. Environmental Entomology 23:254-266.

Ohnesorge, B. and G. Rapp. 1986. Methods for estimating the density of whitefly nymphs (Bemisia tabaci Gennadius) in cotton. Tropical Pest Management 32:207-211.

Perkins, H.H. 1983, Identification of processing of honey dew contaminated cottons. Textile Research Journal : 508-512.

Pollard, D.G. 1955. Feeding habits of the cotton whitefly, Bemisia tabaci Gennadius). (Homoptera : Aleyrodidae). Annals of Applied Biology 3: 664-671.

Rao, N.V., A.S. Reddy, B.R. Rao and G. Satyanarayana. 1991. Interplant distribution of whitefly (Bemisia tabaci Gennadius) on cotton. Gossypium hirsutum L.Journal of Insect Science 4: $32-36$

Schuster, D.J., P.H. Everett, J.F. Price and J.B. Karing. 1989. Suppression of the Sweet Potato whitefly on commercial fresh market tomatoes. Proc. Fl. State Hort. Soc. 102 : 374379 .

Singh, S., Z.S. Dhaliwal. S.S. Sidhu and A.S. Sidhu. 1990. Temporal changes in the dispersion of populations of three homopterous insect pests of upland cotton.Insect Sci. Applic. $11: 73-77$

Southwood, T.R.E. 1978. Ecological methods. 2nd Edition. Methuen and Co. Ltd. London, U.K.

Published with the approval of the College of Agriculture, Sultan Qaboos University as paper No. 110996. 